\title{
IAMJ
}

INTERNATIONAL

AYURVEDIC

MEDICAL JOURNAL

\section{A CONTROLLED CLINICAL STUDY TO EVALUATE THE EFFICACY OF MUSHKAKADI GANA KASHAYA AND VARUNADI KWATHA IN THE MANAGEMENT OF MUTRASHMARI Vis a Vis "UROLITHIASIS"}

\author{
Pradeep $^{1}$, Shripathi Acharya ${ }^{2}$, Pramod Shet ${ }^{3}$ \\ ${ }^{1}$ Final year PG Scholar, Department of Kayachikitsa, Muniyal Institute of Ayurveda Medical Sciences, Manipal, \\ 576104 \\ ${ }^{2}$ Director Academic and WHO Collaborator, Muniyal Institute of Ayurveda Medical Sciences, Manipal, 576104 \\ ${ }^{3}$ Associate Professor, Department of Kayachikitsa, Muniyal Institute of Ayurveda Medical Sciences, Manipal, \\ 576104
}

Corresponding Author: pradeepayu36@gmail.com

\section{https://doi.org/10.46607/iamj1708092020}

(Published online: September 2020)

Open Access

(C) International Ayurvedic Medical Journal, India 2020

Article Received: 01/09/2020 - Peer Reviewed: 07/09/2020 - Accepted for Publication: 09/09/2020

\section{(D) Check for updates}

\section{ABSTRACT}

The genitourinary system is the most important part of human being. Ashmari, one among the Mahagada. Mutrashmari as a variant equated to urolithiasis is the most common ailment of the genitourinary system. In the present study, Mushkakadi Gana Kashaya an effective safe remedy in Ayurveda was evaluated. In the present study, 40 patient's urolithiasis from OPD/IPD of Muniyal Institute of Ayurveda Medical sciences, Manipal. It was a comparative study to evaluate the effect of Mushkakadi Gana Kashaya and Varunadi Kashaya, with a pre-test and posttest design. The assessment of therapy was done by suitable scoring methods which were critically analysed. The results thus obtained were subjected to statistical analysis. The end results thus obtained and graded according to various grades. The study showed Mushkakadi gana was effective in management of Ashmari.

Keywords: Mushkakadi gana kashaya, Varunadi kwatha, Mutrashmari Urolithiasis.

\section{INTRODUCTION}


Ayurveda is an ancient science of life, originated from 5000 years. The basis of which comprises the promotion and maintenance of life. One requires the harmony of not only the Tridosha, but also various functional components like Srotas of the body, through which the Dosha circulate. Amongst which Mutravaha Srotas is one of the most important components, comprising which is a component of Basti-one of Trimarma which enjoys the supreme importance. Various diseases have been mentioned with regards to the affliction of Mutravaha Srotas, but the most important dominant clinical problem nowadays is Murashashmari. It is considered as Mahagada by Sushruta, which is of Tridoshic origin. It is also considered as - Daruna Vyadhi $i^{2}$ because of the excruciating pain with which it presents. In contemporary medical science it is correlated with Urolithiasis

The process of forming stones in the kidney, bladder and Urethra. Urinary stones are the most common cause of blood in urine. Urinary calculi occur around 1 in 20 people at some point of time in their life. In the present era there are many treatment modalities like conservative, surgical, mechanical methods, which fail in eradicating the root cause $\&$ also are not cost effective $^{3}$. There is mentioning of various formulations in the classical texts which work on Samprapti of the illness rather than offering temporary relief from the ailment. Henceforth the study focusses on the evaluation of an important polyherbal formulation in the form of Mushkakadi Gana Kashaya4.

\section{Objective of Study:}

1.To Evaluate the efficacy of the Mushkakadi Gana Kashaya in the management of Mutrashmari (Urolithiasis)

2.To compare and ascertain the efficacy of Mushkakadi Gana Kashaya and Varunadi Kwatha ${ }^{5}$ in the management of Mutrashmari.

\section{Materials and Methods}

Study Design: Single blind randomised comparative clinical study with pre test and post test.

A) Sample source: Patients attending OPD and IPD of the Department of Kayachikitsa, Muniyal Institute of Ayurveda Medical Sciences, Manipal, Udupi. Were randomly selected.
B) Drug source: Ingredients was procured from authentic vendor, approved by Dravyaguna expert from $\mathrm{Mu}-$ niyal Institute of Ayurvedic Medical sciences.

Preparation of medicine was done in Muniyal Pharmacy Manipal.

Selection of cases.

SAMPLE SIZE: A total of 40 patients were selected patients having classical symptomatology of Mutrashmari (Urolithiasis).

\section{A) Inclusion criteria}

1. Age: between 18 to 60 years

2. Sex: either sex

3. Radiological evidence of calculus (up to $10 \mathrm{~mm}$ ) in kidney, ureter or urinary bladder

\section{B) Exclusion criteria}

1. Age below 18 years and above 60 years

2. calculus size more than $10 \mathrm{~mm}$

3. Impacted calculus

4. Gross hydronephrosis

5. Pyelonephritis

6. Malignancy

7. Patients with obstruction in urinary passage

8. Patients with known metabolic abnormality for calculus formation

9. Any other complication of calculus

10. Patients undergoing treatment for any other serious illness.

\section{Intervention:}

40 patients complaining of Mutrashmari were randomly divided into the following two groups, each comprising of 20 patients each.

- First Group A: Mushkakadi Gana kashaya.

- Second Group B: Varunadi Kwatha.

\section{Dosage:}

Group A: Mushkakadigana kashaya-50 $\mathrm{ml}$ twice morning and evening half an hour before the food for 45 days.

Group B: Varunadikwatha $-50 \mathrm{ml}$ twice with added Prakshepaka Dravyas jaggery 12 gms and Yavakshara 3 gms each morning and evening half an hour before food.

Follow Up:15 Days After the completion of medicine. Duration of Medication:45 days 
Withdrawal Criteria - Any adverse drug reactions of the drug will be withdrawn.

Table 1: Drugs of Mushkakadi Gana Kashaya

\begin{tabular}{|l|l|l|l|}
\hline Drug name & Part used & Botanical name & Quantity in gms \\
\hline Mushkaka (Krisnapatala) & Bark & Stereospermum suaveolns & 3 gms \\
\hline Sruga(Snuhiguda) & Stem & Euphorbia nerifolia linn & 3 gms \\
\hline Amalaki & Fruit & Emblica officinalis & 3 gms \\
\hline Haritaki & Fruit & Terminalia chebula & 3 gms \\
\hline Vibhitaki & Fruit & Terminalia bellirica Roxb & 3 gms \\
\hline Dvipi(citraka) & Root & Plumbago zeylanica & 3 gms \\
\hline Palasa & Bark & Butea monosperma & 3 gms \\
\hline Dhava & Bark & Anogeissus latifoli wall & 3 gms \\
\hline Simsipa & Bark & Dalbergia sissoo Roxb & 3 gms \\
\hline
\end{tabular}

Table 2: Drugs of Varunadi Gana

\begin{tabular}{|l|l|l|l|}
\hline Drug name & Part used & Botanical name & Quantity in gms \\
\hline Varuna & Bark & Crataeva nurvala & 12 gms \\
\hline Sunthi & Rhizome & Zingiber officinale & 2 gms \\
\hline Goksura & Fruit & Tribulus terrestris & 10 gms \\
\hline
\end{tabular}

Prakshepakadravyas- Yavakshara-3gms, Jaggery$12 \mathrm{gms}$

Method of preparation of Drug: 6

The drugs of group A/ group B were taken each in coarse powder form. After coarse powder add 8 parts of water boiled and reduced to one fourth. The decoction was filtered and given to the patients.

\section{Investigations}

Urine Examination

1. Routine:

2. $\mathrm{pH}$ :

3. Microscopic

Blood

4. $\mathrm{Hb}(\mathrm{g} / \mathrm{dl})$ :

5. TLC

6. DLC

7. ESR

8. Blood Sugar- FBS AND PPBS

9. B. Urea (mg./dl)

10. S. Uric Acid

11. S. Creatinine $(\mathrm{mg} / \mathrm{dl})$
Ultrasound - Abdomen and Pelvis

1. Size

2. Hydronephrosis

3. Thickness of parenchyma

4. Ureter

5. Bladder

\section{Assessment Criteria}

In this section, parameter of study, criteria of scoring and criteria for assessment of therapy is discussed.

Parameters of Study:

Criteria For Examination And Assessment -

1.Assessment was done on the basis of relief in signs and symptoms of urolithiasis.

2.Other investigation findings (laboratory as well as USG) on the basis of specially designed research proforma through scoring pattern.

\section{Subjective criteria:}

Assessment of therapy was done according to the relief observed in the signs and symptoms with the help of following scoring pattern. 
Table 3: Assessment Criteria Scores

\begin{tabular}{|l|l|l|l|}
\hline & Subjective parameters & No pain & 0 \\
\hline & Pain & Occasional pain & 1 \\
\hline & & Constant dull ache pain & 2 \\
\hline & & Severe constant pain & 3 \\
\hline 2 & Burning micturition & No burning micturition & 0 \\
\hline & & Occasional burning micturition & 1 \\
\hline & & Constant burning micturition & 2 \\
\hline & & Severe burning micturition & 3 \\
\hline & Objective parameters & & \\
\hline 1 & Renal angle tenderness & No tenderness & 0 \\
\hline & & Mild tenderness & 1 \\
\hline & & Moderate tenderness & 2 \\
\hline & & Severe tenderness & 3 \\
\hline 2 & Size of Calculi & No calculi & 0 \\
\hline & & Upto 3.5 mm & 1 \\
\hline & & Between $3.6-7$ mm & 2 \\
\hline & & Between 7.1 -10mm & 3 \\
\hline 3 & Haematuria & No RBC & 0 \\
\hline & & $0-5$ RBC/HPF & 1 \\
\hline & & $6-10$ RBC/HPF & 2 \\
\hline & & $>10$ RBC/ HPF & 3 \\
\hline
\end{tabular}

Follow ups and Results

4 follow ups- on 15th day, on 30th day, on 45th day and on 60th day

Those cases, which were in regular follow ups for 45 days were taken for clinical study. The criteria of assessment were mainly on the subjective and objective parameters. Intermediate follow ups were recorded at interval of 15 days. Observation for relief in sign and symptoms in all follow up was done. Last follow up was recorded to see the improvement.

\section{Data analysis methods}

Most of the signs \& symptoms of Mutrashmari described are subjective in nature, and for statistical analysis scoring system has been adopted. Statistical analysis and percentage of relief (before and after treatment) was taken to know the efficacy of the trial drugs.
Statistical Assessment -

To evaluate this, total scores observed before treatment (B.T.) and after treatment (A.T.). Average of respective scores is calculated and percentage of change/ improvement is drawn by following formula:

\section{Average BT- Average AT X 100 \\ Average BT}

To assess the effect of drugs on by applying student paired " $t$ " test for within the group, for between the group unpaired test ' $t$ ' was used. The obtained results were interpreted as: -

- Non-Significant $>0.05$

- Significant $<0.05$

- Highly Significant $\mathrm{P}<0.001$

- Extremely significant $\mathrm{P}<0.0001$ 


\section{Results}

Table 4: Comparison Within the Group A

\begin{tabular}{|c|c|c|c|c|c|c|c|c|c|c|}
\hline & & Mea & n Score & & $\%$ & SD & SEM & $\mathbf{T}$ & $\mathbf{P}$ & SIGNF. \\
\hline & BT & & & Mean Diff & & & & & & \\
\hline Pain & 1.95 & AT & 0.65 & 1.30 & 66.6 & 0.470 & 0.105 & 12.365 & $<0.0001$ & ES \\
\hline & & $\mathrm{AF}$ & 0.35 & 1.60 & 82.0 & 0.502 & 0.112 & 14.236 & $<0.0001$ & ES \\
\hline Burning micturition & 1.65 & AT & 0.60 & 1.05 & 63.6 & 0.686 & 0.153 & 6.842 & $<0.0001$ & ES \\
\hline & & $\mathrm{AF}$ & 0.30 & 1.35 & 81.8 & 0.587 & 0.131 & 10.283 & $<0.0001$ & ES \\
\hline Tenderness & 1.30 & AT & 0.65 & 0.65 & 50.0 & 0.587 & 0.131 & 4.951 & $<0.0001$ & ES \\
\hline & & $\mathrm{AF}$ & 0.45 & 0.85 & 65.3 & 0.670 & 0.150 & 5.667 & $<0.0001$ & ES \\
\hline Size of stone & 5.71 & AT & 1.425 & 4.285 & 75.1 & 1.440 & 0.322 & 13.303 & $<0.0001$ & ES \\
\hline & & $\mathrm{AF}$ & 1.05 & 4.660 & 81.6 & 1.416 & 0.316 & 14.719 & $<0.0001$ & ES \\
\hline Haematuria & 0.55 & AT & 0.30 & 0.25 & 45.5 & 0.444 & 0.099 & 2.517 & 0.0210 & $\mathrm{~S}$ \\
\hline & & $\mathrm{AF}$ & 0.15 & 0.50 & 90.1 & 0.598 & 0.133 & 2.990 & 0.0075 & VS \\
\hline Number of stones & 2.30 & AT & 0.95 & 1.35 & 58.6 & 0.988 & 0.220 & 6.110 & $<0.0001$ & ES \\
\hline & & $\mathrm{AF}$ & 0.65 & 1.65 & 71.7 & 1.226 & 0.274 & 6.020 & $<0.0001$ & ES \\
\hline
\end{tabular}

Table 5 Comparison Within the Group B

\begin{tabular}{|c|c|c|c|c|c|c|c|c|c|c|}
\hline & \multirow[b]{2}{*}{ BT } & \multicolumn{3}{|c|}{ Mean Score } & \multirow[t]{2}{*}{$\%$} & \multirow[t]{2}{*}{ SD } & \multirow[t]{2}{*}{ SEM } & \multirow[t]{2}{*}{$\mathbf{T}$} & \multirow[t]{2}{*}{$\mathbf{P}$} & \multirow[t]{2}{*}{ SIGNF. } \\
\hline & & & & $\begin{array}{l}\text { Mean } \\
\text { Diff }\end{array}$ & & & & & & \\
\hline \multirow[t]{2}{*}{ Pain } & \multirow[t]{2}{*}{1.90} & $\mathrm{AT}$ & 0.70 & 1.20 & 63.1 & 0.414 & 0.091 & 13.077 & $<0.0001$ & ES \\
\hline & & $\mathrm{AF}$ & 0.40 & 1.50 & 78.9 & 0.513 & 0.114 & 13.077 & $<0.0001$ & ES \\
\hline \multirow[t]{2}{*}{ Burning micturition } & \multirow[t]{2}{*}{1.40} & AT & 0.45 & 0.95 & 67.8 & 0.510 & 0.1141 & 8.324 & $<0.0001$ & ES \\
\hline & & $\mathrm{AF}$ & 0.45 & 0.95 & 67.8 & 0.510 & 0.1141 & 8.324 & $<0.0001$ & ES \\
\hline \multirow[t]{2}{*}{ Tenderness } & \multirow[t]{2}{*}{0.80} & AT & 0.55 & 0.25 & 31.2 & 0.444 & 0.099 & 2.517 & 0.0210 & $\mathrm{~S}$ \\
\hline & & $\mathrm{AF}$ & 0.45 & 0.35 & 43.7 & 0.587 & 0.131 & 2.666 & 0.0153 & $\mathrm{~S}$ \\
\hline \multirow[t]{2}{*}{ Size of stone } & \multirow[t]{2}{*}{6.425} & AT & 1.82 & 4.605 & 71.6 & 1.560 & 0.348 & 13.203 & $<0.0001$ & ES \\
\hline & & $\mathrm{AF}$ & 1.82 & 4.605 & 71.6 & 1.560 & 0.348 & 13.203 & $<0.0001$ & ES \\
\hline \multirow[t]{2}{*}{ Haematuria } & \multirow[t]{2}{*}{0.70} & AT & 0.3 & 0.40 & 57.1 & 0.502 & 0.112 & 3.559 & 0.0021 & VS \\
\hline & & $\mathrm{AF}$ & 0.3 & 0.40 & 57.1 & 0.502 & 0.112 & 3.559 & 0.0021 & VS \\
\hline \multirow[t]{2}{*}{ Number of stones } & \multirow[t]{2}{*}{3.05} & AT & 1.20 & 1.85 & 60.6 & 1.040 & 0.232 & 7.995 & $<0.0001$ & ES \\
\hline & & $\mathrm{AF}$ & 0.95 & 2.10 & 68.9 & 1.021 & 0.228 & 9.200 & $<0.0001$ & ES \\
\hline
\end{tabular}

Table 6: Comparison Between the Groups

\begin{tabular}{|l|l|l|l|l|l|l|l|l|l|}
\hline & \multicolumn{9}{|l|}{ Comparison Between The Group } \\
\hline Group & N & Mean & SD & $\begin{array}{l}\text { Mean } \\
\text { Diff }\end{array}$ & t & p & Significant \\
\hline Pain & AT & & & & & \\
& A & 20 & 0.65 & 0.812 & 0.05 & 0.2043 & 0.8392 & NS \\
\hline & B & 20 & 0.70 & 0.732 & & & & \\
\hline & AF & & & & & & \\
& A & 20 & 0.35 & 0.489 & 0.05 & 0.3188 & 0.7517 & NS \\
\hline & B & 20 & 0.40 & 0.502 & & & & \\
\hline Burning Micturition & AT & & & & & & & \\
\hline & A & 20 & 0.60 & 0.753 & 0.15 & 0.7368 & 0.4658 & NS \\
\hline
\end{tabular}




\begin{tabular}{|c|c|c|c|c|c|c|c|c|}
\hline & B & 20 & 0.45 & 0.510 & & & & \\
\hline & \multicolumn{8}{|c|}{$\mathrm{AF}$} \\
\hline & A & 20 & 0.30 & 0.470 & \multirow[t]{2}{*}{0.15} & \multirow[t]{2}{*}{0.9667} & \multirow[t]{2}{*}{0.3398} & \multirow[t]{2}{*}{ NS } \\
\hline & B & 20 & 0.45 & 0.510 & & & & \\
\hline \multirow[t]{7}{*}{ Tenderness } & \multicolumn{8}{|c|}{$\mathrm{AT}$} \\
\hline & A & 20 & 0.65 & 0.812 & \multirow[t]{2}{*}{0.10} & \multirow[t]{2}{*}{0.4204} & \multirow[t]{2}{*}{0.6766} & \multirow[t]{2}{*}{ NS } \\
\hline & $\mathrm{B}$ & 20 & 0.55 & 0.686 & & & & \\
\hline & \multicolumn{8}{|c|}{$\mathrm{AF}$} \\
\hline & $\mathrm{A}$ & 20 & 0.45 & 0.686 & \multirow[t]{2}{*}{0.00} & \multirow[t]{2}{*}{0.000} & \multirow[t]{2}{*}{$>0.999$} & \multirow[t]{2}{*}{ NS } \\
\hline & $\mathrm{B}$ & 20 & 0.45 & 0.604 & & & & \\
\hline & \multicolumn{8}{|c|}{ AT } \\
\hline \multirow[t]{5}{*}{ Size Of Stone } & A & 20 & 1.425 & 1.696 & \multirow[t]{2}{*}{0.395} & \multirow[t]{2}{*}{0.6834} & \multirow[t]{2}{*}{0.4985} & \multirow[t]{2}{*}{ NS } \\
\hline & $\mathrm{B}$ & 20 & 1.820 & 1.951 & & & & \\
\hline & \multicolumn{8}{|c|}{$\mathrm{AF}$} \\
\hline & $\mathrm{A}$ & 20 & 1.050 & 1.538 & \multirow[t]{2}{*}{0.770} & \multirow[t]{2}{*}{1.386} & \multirow[t]{2}{*}{0.1738} & \multirow[t]{2}{*}{ NS } \\
\hline & $\mathrm{B}$ & 20 & 1.820 & 1.951 & & & & \\
\hline \multirow[t]{7}{*}{ Number Of Stones } & \multicolumn{8}{|c|}{$\mathrm{AT}$} \\
\hline & $\mathrm{A}$ & 20 & 0.95 & 1.146 & \multirow[t]{2}{*}{0.25} & \multirow[t]{2}{*}{0.5659} & 0.5748 & NS \\
\hline & $\mathrm{B}$ & 20 & 1.20 & 1.609 & & & & \\
\hline & $\mathrm{AF}$ & & & & & & & \\
\hline & $\mathrm{A}$ & 20 & 0.65 & 1.089 & 0.30 & 0.7850 & 0.4373 & NS \\
\hline & $\mathrm{B}$ & 20 & 0.95 & 1.317 & & & & \\
\hline & AT & & & & & & & \\
\hline Hematuria & $\mathrm{A}$ & 20 & 0.30 & 0.571 & 0.0 & 0.000 & $>0.999$ & NS \\
\hline & B & 20 & 0.30 & 0.470 & & & & \\
\hline & $\mathrm{AF}$ & & & & & & & \\
\hline & $\mathrm{A}$ & 20 & 0.15 & 0.366 & 0.15 & 1.125 & 0.2675 & NS \\
\hline & B & 20 & 0.30 & 0.470 & & & & \\
\hline
\end{tabular}

Table 7- Overall Effect Of Muskhakadi Gana

\begin{tabular}{|l|l|l|l|}
\hline Total Effect & Percentage & No Of Patients & \% Of Relief \\
\hline Cured & $100 \%$ & 4 & 20 \\
\hline Markedly Improved & $76-99 \%$ & 7 & 35 \\
\hline Mild Improvement & $51-75 \%$ & 8 & 40 \\
\hline Improvement & $25-50 \%$ & 1 & 5 \\
\hline No Improvement & $<25 \%$ & 0 & 0 \\
\hline
\end{tabular}




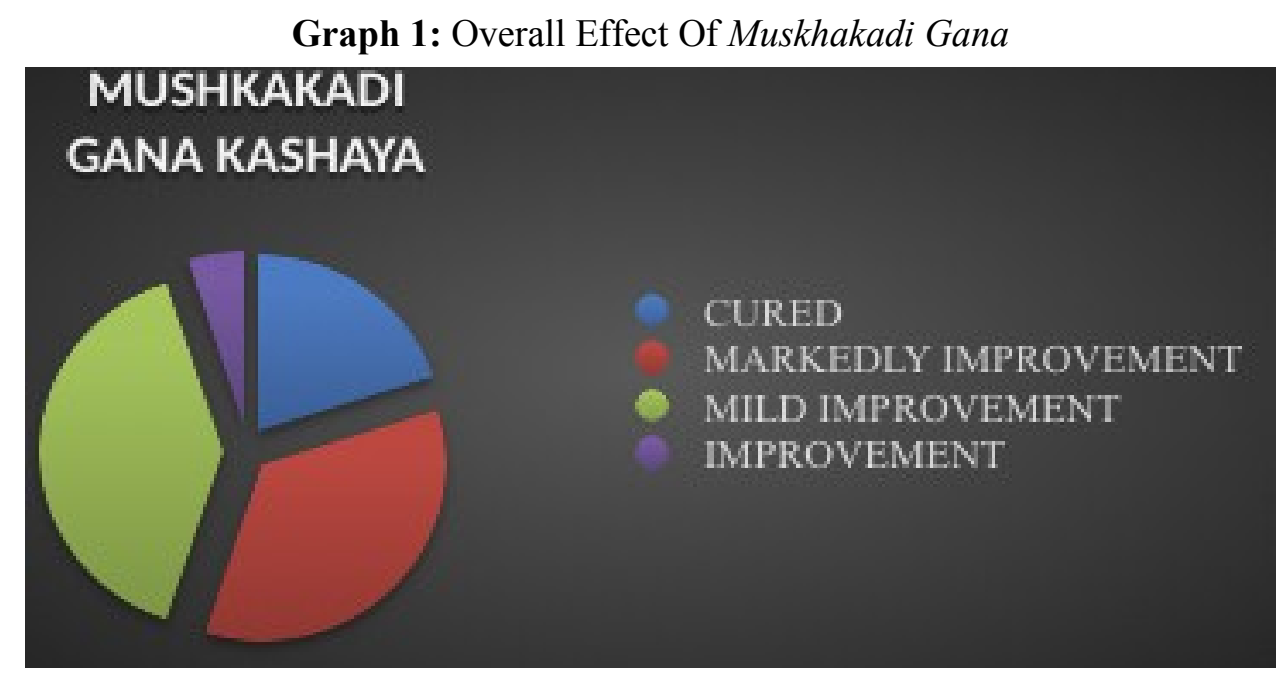

Table 8: Overall Effect Of Varunadi Kashaya

\begin{tabular}{|l|l|l|l|}
\hline Total Effect & Percentage & No of Patients & \% of Relief \\
\hline Cured & $100 \%$ & 1 & 5 \\
\hline Markedly Improved & $76-99 \%$ & 4 & 20 \\
\hline Mild Improvement & $51-75 \%$ & 10 & 50 \\
\hline Improvement & $25-50 \%$ & 5 & 2 \\
\hline No Improvement & $<25 \%$ & 0 & 0 \\
\hline
\end{tabular}

Graph 2: Overall Effect Of Varunadi Kashaya

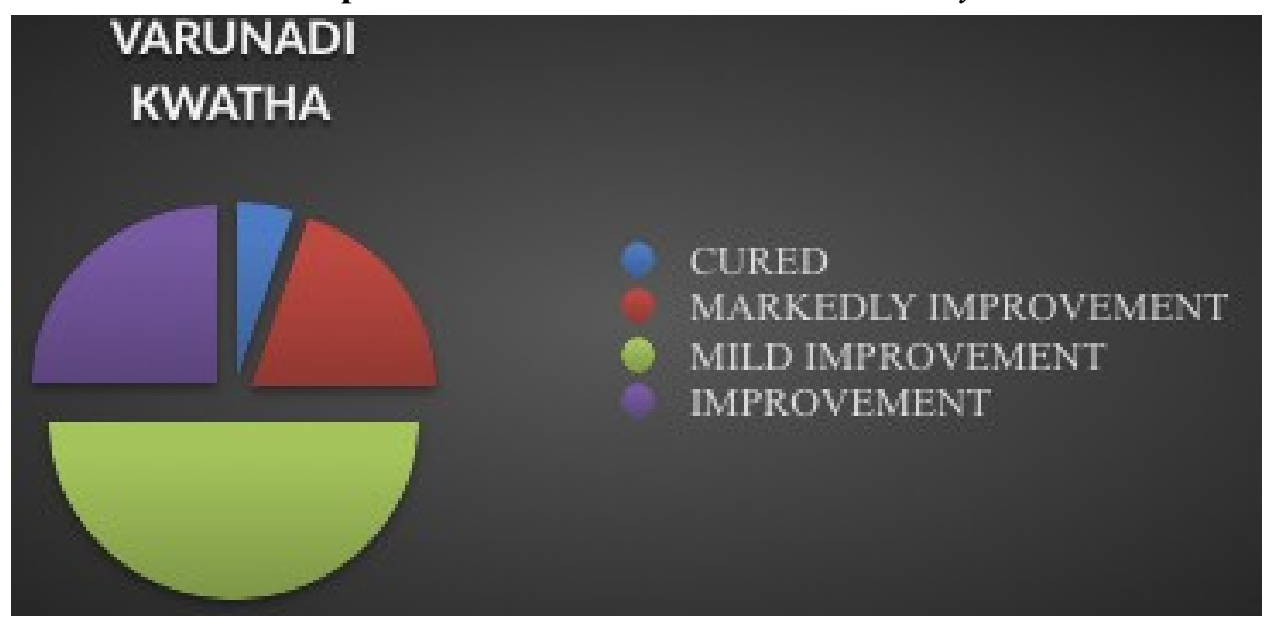

Table 9: Group A-Effect of therapy in number \& size

\begin{tabular}{|c|c|c|c|c|c|c|}
\hline \multirow[b]{2}{*}{ Expelled Out } & \multicolumn{2}{|c|}{$0-3.5 \mathrm{~mm}(\%)$} & \multicolumn{2}{|c|}{$3.6-7 \mathrm{~mm}(\%)$} & \multicolumn{2}{|c|}{$7.1-10 \mathrm{~mm}(\%)$} \\
\hline & 2 & $10 \%$ & 10 & $50 \%$ & 1 & $5 \%$ \\
\hline Decrease In Size & $\mathbf{0}$ & $\mathbf{0}$ & 3 & $15 \%$ & 4 & $20 \%$ \\
\hline No Change & $\mathbf{0}$ & $\mathbf{0}$ & $\mathbf{0}$ & $\mathbf{0}$ & $\mathbf{0}$ & $\mathbf{0}$ \\
\hline Increase In Size & $\mathbf{0}$ & $\mathbf{0}$ & $\mathbf{0}$ & $\mathbf{0}$ & $\mathbf{0}$ & $\mathbf{0}$ \\
\hline
\end{tabular}




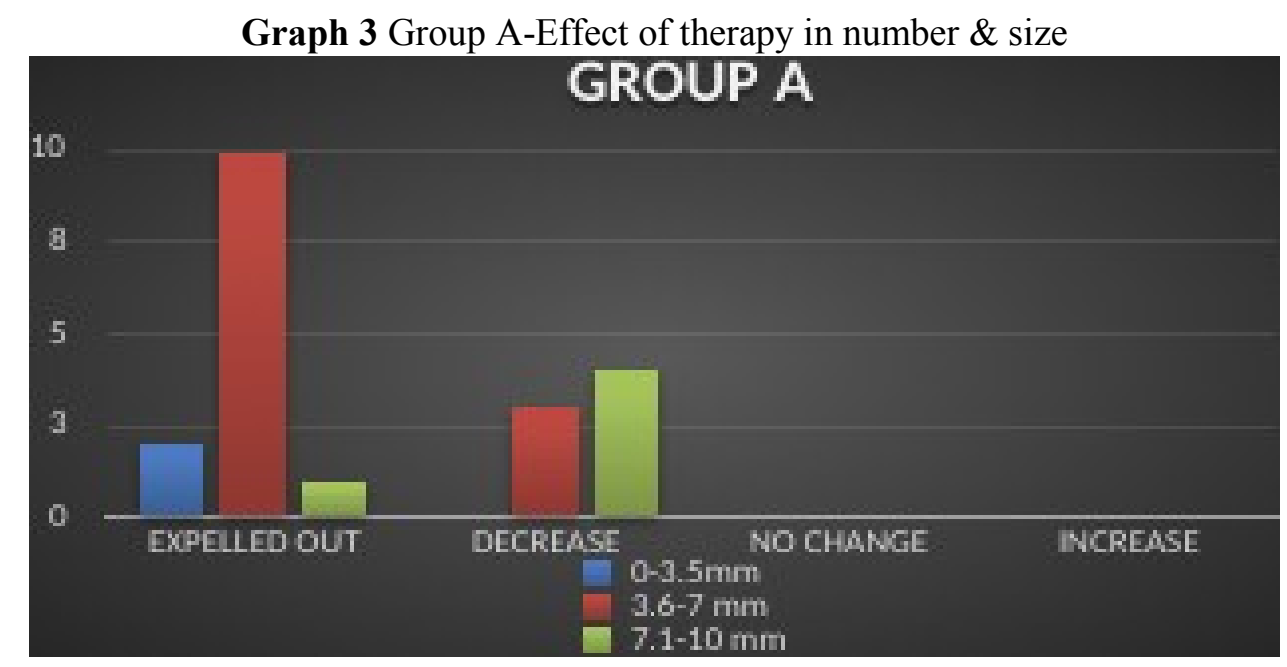

Table 10: Group B-effect of therapy in number \& size

\begin{tabular}{|l|l|l|l|l|l|l|}
\hline & $\mathbf{0 - 3 . 5} \mathbf{m m} \mathbf{( \% )}$ & $\mathbf{3 . 6 - 7 m m} \mathbf{( \% )}$ & $\mathbf{7 . 1 - 1 0 m m ~ ( \% )}$ \\
\hline Expelled Out & 0 & 0 & 9 & $45 \%$ & 1 & $5 \%$ \\
\hline Decrease In Size & 0 & 0 & 4 & $20 \%$ & 6 & $30 \%$ \\
\hline No Change & 0 & 0 & 0 & 0 & 0 & 0 \\
\hline Increase In Size & 0 & 0 & 0 & 0 & 0 & 0 \\
\hline
\end{tabular}

Graph 4: Group B-effect of therapy in number \& size

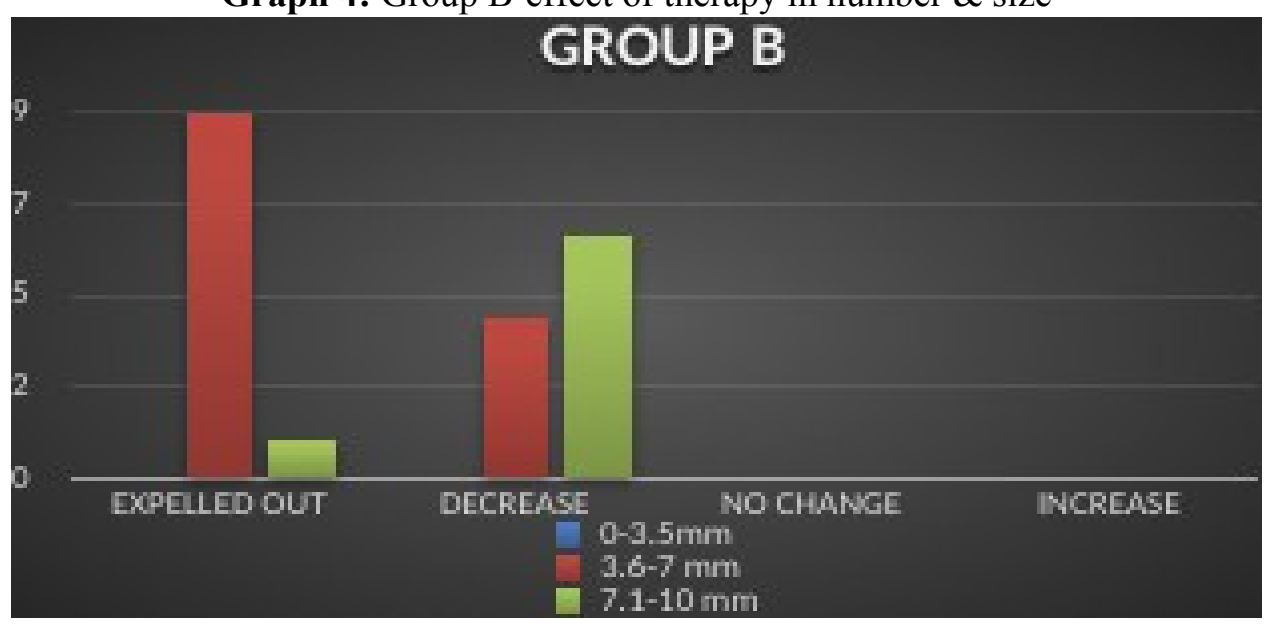

\section{DISCUSSION}

\section{Mode Of Action Of Mushkakadi Gana}

Muskhakadi Gana is a polyherbal formulation. The herbs have the properties like Katu-Tikta-kashaya Rasa, Ushna veerya, Katu Vipaka. The overall effect of the formulation is dominantly Tridoshahara in nature. Mutashmari is known Tridoshic in nature, but Kapha dosha is the main contributing factor in the pathogenesis of Mutrashmari, which is evident with the pathological sequel of stagnation. Stagnation of urine leads to concentration, infection \& thereby increased risk of calculi formation. Hence, the main line of treatment should be Kaphahara, Srotoshodhana, Vata anulomana, Agni Vardhana, Ashmari Hara, Mutrala, Vedanasthapana.

Pain control is an important measure to be taken in Mutrashmari. Acute spasmodic or colicky pain results 
when calculus moves downwards through the urinary tract or lodges at a certain junction.

The drugs in Mushkakadi drug like Mushkaka, Sruga, Amalaki, Haritaki, Vibhitaki, Dvipi (Chitraka), Palasa, Dhava and Simsipa possess Vedanasthapana Property. The Vatanulomana, Shothahara and Mutrala properties of the above ingredients help to relieve pain.

Ingredients such as Chitraka, Palasa and Sruga have properties of Deepana, Pachana which helps to maintain the Agni and prevent formation of Ama at Jataragni level.

Most of the drugs in Mushkakadi gana possess Laghu, Ruksha properties such as Mushkaka, Amalaki, Vibhitaki, Haritaki, Chitraka, Palasa, Simsipa which do Lekhana of excess Kapha. It also clears out the Srothorodha due to Laghu, Ruksha and Tikshana properties, simultaneously pacifies kapha and ultimately helps in crushing and expulsion of the calculi. The Bhedana property of Vibhitaki also helps in breaking the calculi and expulsion of the same.

The drugs Amalaki, Haritaki, Vibhitaki, Chitraka do Vatanulomana thereby helping in expulsion of the Ashmari and also reduces pain.In Mushkakadi Gana, the drug Amalaki which has Pancha Rasa (Madhura rasa) Sheeta Virya acts as Mutrala.

Haematuria occurs due to injury to the urinary system by the projecting part. Drugs like Amalaki, Mushkaka, Vibhitaki, Haritaki, Palasa, Simsipa possess Kashaya Rasa which does the action of Stambhana thereby stopping or reducing haematuria, also Amalaki possesses Sheeta Virya which also does Stambhana.

Tenderness occurs due to inflammation of the urinary tract. The Mutrala activity of the Amalaki along with Jwaragna properties of Sruga, Shothahara properties of Sruga, Amalaki, Haritaki, Chitraka and Simsipa helps in reducing tenderness.

Rasayana effect of Amalaki helps in overall improvement and prevention of further occurrence.

\section{Mode of Action of Varunadi Kwatha}

Varunadi kwatha possess all the needful properties like Kaphahara, Lekhana and Mutrala. The ingredients of the compound pacify Kapha Dosha by virtue of their Ruksha Guna, Katu Vipaka and Ushna Virya and also show Lekhana property due to Ushna virya.
Yavakshara has the property of Lekhana. Vatanulomana, Shothahara and Mutrala properties of ingredients helps to relieve pain and Sthanikashotha. Jwara is also relieved due to the Jwarahara action of Varun and shunti. Deepana property of the drug helps to increase the agni which further checks the formation of Ama at Jataragni level. All the ingredients of the drug, by their Bhedana, Ashmarihara and Kaphahara Karmas along with Mutrala Karma, are helpful to reduce the size of the Ashmari and expel it out from the body.

\section{CONCLUSION}

Muskakadi Gana Kashaya is Ashmari is a disease of Mutravaha srotas caused when the Kapha Pradhana Dosha comes into the Basti (urinary system) along with Mutra. Two major aetiological factors are Ashamshodhana and Apathya Sevana. Ashmari can be compared to the condition of Urolithiasis irrespective of whether it is found in Kidney, Ureter, Bladder or Urethra. After treatment group A showed more improvement in pain, tenderness, size of stone, while group B showed improvement in Burning micturition, number of stone and Haematuria. After following up Group A showed improvement in all subjective and objective parameters. Better results may be achieved by observing the findings in larger population and also by studying their effect on different type (chemical composition) of stone.

\section{REFERENCES}

1. Sushruta, Sushruta Samhita, (Nibandhasangraha commentary of Sri Dalhanacharya and Nyayachandrika Panjika of Sri Gayadas Acharya of Nidana sthana Acharya Vaidya Yadavji Trikamji), Varanasi, Chaukhambha Sanskrit Sansthana, Reprint 2005, Nidana sthana 33/4, Pp 824, P 144.

2. Sushruta, Sushruta Samhita, by Prof. K.R. Srikanth Murthy, Chikitsa sthana, 7/ 3, Edition Reprint 2016, Vol. II, Chaukhambha Orientalia Varanasi, Pp- 516, P 87

3. https://www.medicinenet.com/script/main/art.asp?articlekey $=6649$

4. Vagbhata's Ashtanga Hrdayam, English Translation by Prof. K.R. Srikantha Murthy, Sutrasthana, 15/32, Edition reprint 2016, vol I, Chaukhambha Krushnadas Academy Varanasi, Pp 520, P 205 
5. Govind Dasji, Bhaishajya Ratnavali of Bhisagratna,, commented by Vaidya Shri Ambika Datta Shastri by Dr. Lochan Kanjiv, 36/ 3, 1st Edition 2006, Chaukhamba Sanskrit Sansthana Varanasi, P 483, Pp 799.

6. Sharangdhara Samhita, English Translation by Prof. K.R. Srikantha Murthy, 2/1,2,3, 6th edition 2006, Pub: Chaukhambha Orientalia Varanasi, Pp335, P 56

\section{Source of Support: Nil \\ Conflict of Interest: None Declared}

How to cite this URL: Pradeep et al: A Controlled Clinical Study To Evaluate The Efficacy Of Mushkakadi Gana Kashaya And Varunadi Kwatha In The Management Of Mutrashmari Vis A Vis "Urolithiasis". International Ayurvedic Medical Journal \{online\} 2020 \{cited September, 2020\} Available from:

http://www.iamj.in/posts/images/upload/4402_4410.pdf 